\title{
"Jeg er en kvinde" Kroppen som baggrund i "Det andet køn"
}

Kan man som kvinde tanke teori uden at negligere sin konnede krop? Med afsat i Simone de Beauvoirs "Det andet køn", kommer Toril Moi med opervejelser og bud pai en løsning af dette skisma.

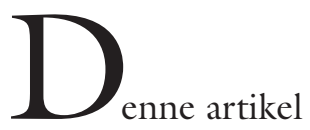

er et kort uddrag af et meget længere essay med titlen "I am a woman. The Personal and the Philosophical". ${ }^{1}$ (Essayet udgør kapitel 2 i min kommende bog med titlen "What is a Woman? And Other Essays", som udgives af Oxford University Press i oktober 1999. I mit essay om "The Personal and the Philosophical" begynder jeg med at stille et meget enkelt spørgsmål: Hvordan kan jeg formulere teori eller filosofi uden at negligere det personlige aspekt? Grunden til, at dette spørgsmål er kommet til at spille en rolle for mig, er, at megen samtidig teori, hvad enten den er feministisk eller ikke-feministisk, hævder, at den eneste måde, hvorpå man kan modgå de autoritære, ekskluderende og diskriminerende virkninger af at tale for (andre), er ved at tale som (den man er). Det antages yderligere, at teori og filosofi nødvendigvis må være undertrykkende, fordi de udgør diskurser, som nødvendigvis søger at universalisere deres resultater. Feminister har 
hævdet, at teori i sig selv er maskulint og sexistisk, fordi det bidrager til en devaluering af følelser og dermed af kvinder. Ydermere er teori og filosofi blevet anskuet som værende af naturen mandlige : Sådanne beskæftigelser er intet andet end en mulighed for konkurrerende ødipal selvpromovering blandt mænd. Kvinder, som finder glæde ved at beskxftige sig med filosofi og teori, er ofte af andre kvinder blevet kaldt kvinder med mandlig identifikation . For at finde eksempler på det, behøver man bare studere modtagelsen af Simone de Beauvoirs værker. $^{2}$

Eftersom jeg er en kvinde, der ønsker at formulere teori, bekymrer den type anklager mig. Meget enkelt udtrykt: Det er umuligt at formulere teori uden at generalisere og universalisere. En mandlig eller kvindelig teoretiker kan ikke nøjes med at udtrykke sin egen erfaring: På et tidspunkt må denne erfaring føre til overvejelser og mere generel analyse. I modsat fald har vi at gøre med selvbiografi (en udmærket genre, men ikke en der kan erstatte teoretisk tænkning). Teori kan ikke opgive sin bestræbelse på at gøre sine udsagn gældende for andre uden at ophøre med at være teori. Men følger det heraf, at teori nødvendigvis må være hoven, upersonlig, arrogant, autoritær og eksklusiv? I det længere essay "I am a woman. The Personal and the Philosophical" forsøger jeg at besvare sådanne spørgsmål ved at diskutere brugen og misbrugen af ad hominem og ad feminem argumenter, af personlig og upersonlig viden og betydningen af begreber som objektivitet og subjektivitet.

En af mine konklusioner i denne del af essayet er, at hvis der er en blindgyde i vor tids tanker om disse spørgsmål, så skyldes det en udbredt mangel på evne til at tænke i andre udtryk end svækkende snævre binære modsætningspar. Jeg vil derfor gå over til at undersøge "Det andet køn" som et konkret eksempel på en alternativ forståelse af relationen mellem det personlige og det filosofiske. Og jeg foretager derfor en indgående nærlæsning af de første tre afsnit i (den franske udgave) af "Det andet køn". Hvor denne artikel er et underafsnit, der omhandler de første otte eller ni linjer af det tredje afsnit, hvor Beauvoir finder det nødvendigt at sige Jeg er en kvinde - at tale personligt - for at fremsætte en vidtrækkende generel påstand om, hvad det betyder at være en kvinde. Når jeg refererer til det, som Beauvoir netop har sagt, eller til det hun går videre med at sige, forudsætter det enten de forudgående to afsnit eller resten af det tredje afsnit.

Efter at have arbejdet mig igennem begyndelsen af "Det andet køn" relaterer jeg Beauvoirs forståelse af, hvordan filosofi kunne se ud, til Stanley Cavells grundige undersøgelser af den måde, hvorpå gængse sprogfilosoffer sætter deres subjektivitet ind som indsats $\mathrm{i}$ deres påstande. På den måde placerer jeg Beauvoir i sammenhæng med Cavell og Wittgenstein og forsøger dermed at påvise, hvilken uhyre stor forskel der er mellem at opfatte sig selv som representant for andre og at opfatte sig selv som et eksempel på en særlig situation eller dilemma. Endelig vil jeg tilføje, at i essayet "What Is a Woman? Sex, Gender and the Body in Feminist Thought", som er kapitel 1 i min kommende bog, diskuterer jeg indgående Beauvoirs påstand om, at kroppen er en situation. Når jeg, i nærværende artikel, går over til at udforske hendes ide om, at kroppen er en fænomenologisk baggrund, skal det forstås sådan, at jeg kun udvikler ét aspekt af Beauvoirs sammensatte og udfordrende filosofi om kropslig subjektivitet.

Men lad os nu vende os mod det centrale tredje afsnit af "Det andet køn" (Jeg forudsætter, at de første to afsnit er læst). I den franske tekst fylder dette afsnit kun to sider, men det udgør en milepæl i feministisk filosofi. Beauvoir indleder med at erklære "Jeg er en kvinde" og slutter af med for første gang at erklære, at kvinden er den Anden. Hvordan kommer hun fra en erklæring om sig selv til et alment udsagn om alle kvinder? Og hvordan besvarer disse ud- 


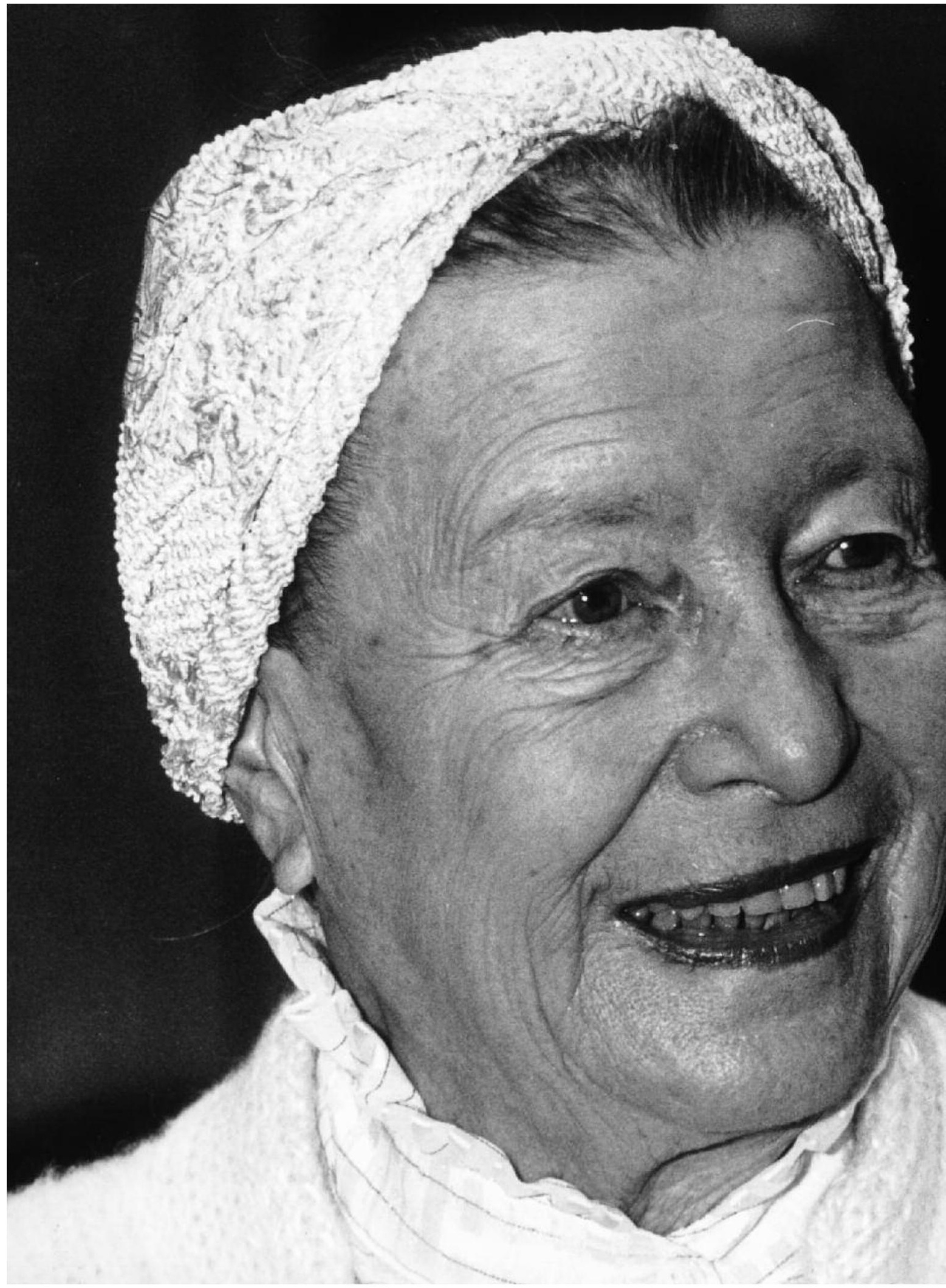


sagn spørgsmålet om, hvad en kvinde er? Hun begynder som følger:

Selve formuleringen af problemet indebærer muligheden af et foreløbigt svar. ${ }^{3}$ Det har betydning, at jeg rejser det. En mand ville aldrig finde på at skrive en bog om den særlige [singulière] situation for mandlige medlemmer af menneskeslægten. ${ }^{4}$ Men hvis jeg vil definere mig selv, må jeg først og fremmest erklære: Jeg er en kvinde!; denne sandhed er baggrunden for alle yderligere udsagn. [cette vérité constitue le fond sur lequel sénlèvera toute autre affirmation]. 5 En mand indleder aldrig med at forsikre, at han er [par se poser comme] et individ af et bestemt køn; at han er en mand, behøver ikke at nævnes (SS xxi; DSa 14; TA).

Nogle feministiske teoretikere føler sikkert, at Beauvoir her vender ryggen til det reelle problem. Måske, kunne man sige, indser hun ubevidst, at selve det at fremsætte spørgsmålet Hvad er en kvinde? fordømmer én til metafysisk essentialisme. Men man kunne argumentere for, at eftersom hun ikke ønsker at indtage en essentialistisk position, forlader hun det teoretiske terræn til fordel for det selvbiografiske. Bekendelse erstatter analyse. Kritikere kunne hævde, at dette er grunden til, at det aldrig lykkes for Beauvoir at teoretisere kønsforskellen, men kun at indsamle mere eller mindre positivistisk information om den. Det er unødvendigt at sige, at jeg mener, det er at drage forhastede - og også ret forudsigelige konklusioner. Jeg vil i stedet mene, at hvis vi udviser tålmodighed i læsningen af denne passage, vil den fremstå som hjørnestenen til en dybt original bestræbelse på at tænke ud over det snævre valg mellem teori og selvbiografi, ud over dikotomien mellem første og tredje person, som genererer så megen samtidig kritik, og, ikke mindst, ud over modsætningen mellem essentialisme og nominalisme.

Ovenstående passage har til formål at besvare spørgsmålet Hvad er en kvinde? Det 
første, Beauvoir gør, er at undersøge talehandlingen bag det oprindelige spørgsmål: Hvem ville finde på at spørge om, hvad en kvinde er? I hvilken situation ville de stille et sådant spørgsmål?

Hendes første opdagelse er, at kønsforskellen manifesterer sig i selve hendes interesse i spørgsmålet (Hun har jo netop erklæret, at det er nok at gå en tur med åbne øjne for at opdage, at mænd og kvinder har forskellige interesser). Passagens struktur er i slående grad symmetrisk. To gange bliver et udsagn om hende selv modstillet med en sætning om, hvad en mand ville gøre eller sige (Jeg rejser spørgsmålet; en mand ville aldrig spørge; Jeg må erklære; en mand indleder aldrig). Strukturen frembringer en stærk kontrast; ikke, som man kunne have forventet, mellem kvinde og mand men mellem jeg og en mand.

Beauvoir indser her, at hun skriver $\mathrm{i}$ en situation, hvor hun, i modsætning til mandlige forfattere, er nødt til at definere sig selv som et kønnet væsen; hvor hun ikke har noget andet valg end at udfylde det tomme felt jeg med sit køn. Det første jeg i bogen - sætningen Jeg har længe tøvet med at skrive en bog om kvinden - var henkastet. Det tog sig selv for givet, uden filosofisk ståhej. Dette jeg ( Jeg er en kvinde, Jeg må definere mig selv etc.) viser tegn på politisk og filosofisk spænding. I denne sætning er ideen om, at kvinden er den Anden, allerede txt på. Men hvis jeg vil definere mig selv, må jeg først og fremmest erklære Jeg er en kvinde; denne sandhed udgør den baggrund, som alle yderligere udsagn må ses ud fra [cette verité constitue le fond sur lequel senlèvera toute autre affirmation].

Formuleringen her er afgørende. På fransk er senlever sur un fond en noget usædvanlig vending, især i denne kontekst. Se détacher ville have været det mere indlysende valg, eftersom ordbogen Le Petit Robert definerer det som at fremstå klart som om det står frem imod en baggrund. Generelt har détacher altid konnotationer af synlig adskillelse, klart afgrænsede konturer, og det bruges således ofte om en farve eller form, som fremhæves imod en afvigende baggrundsfarve. Når Beauvoir vælger at skrive senlever og ikke se détacher, er det formodentlig, fordi hun ønsker at fremhæve en anden betydningsnuance. Mange af de mest almindelige betydninger af enlever er tydeligvis irrelevante for konteksten. Det er ikke sandsynligt, at Beauvoir tænker på betydningerne at kidnappe eller røve, på fjernelse af pletter, eller på at noget bliver taget væk. En af de primære betydninger af enlever er imidlertid at løfte opad $(e n+$ lever $)$, og enlevure er således en teknisk betegnelse for skulpturelt relief. På engelsk kan relief bruges om såvel visuelle som taktile virkninger (reliefkort anvender farver og skraveringer til at angive ophøjninger og sænkninger). På fransk er enlevure imidlertid altid taktilt, en enlevure er noget, jeg skulle kunne føle i mørke. Jeg ønsker ikke at overdrive forskellene mellem disse ord; et skulpturelt relief er også synligt, og hvis jeg er i et landskab, kan jeg røre ved kirken $\mathrm{i}$ forgrunden såvel som ved træerne i baggrunden, men de forskellige sansemæssige kendetegn ved de to ord er indlysende.

Det billede, Beauvoir har i tankerne, er nu tilgængeligt. Det faktum, at hun er en kvinde, er den sandhed, som udgør den baggrund, ud fra hvilken alle yderligere påstande vil fremstå i relief, skriver hun. Der er to fakta her: For det første er det et faktum, at hun er en kvinde. For det andet er det et faktum, at når hun vil definere sig selv, er hun nødt til at understrege dette. Beauvoir betragter det faktum, at hun er en kvinde, som den baggrund, hendes talehandlinger fremstår ud fra. Ordet påstand eller hævdelse [affirmation] angiver, at hun taler om sit eget intellektuelle forehavende: At skrive en bog om kvinder. Ligesom det er tilfældet med alle andre handlinger, definerer mine talehandlinger mig, vil en eksistentialist sige. Hvis jeg er en kvinde, kommer mine påstande uundgåeligt til at 
fremstå på baggrund af mit køn. Det indebærer, at ligegyldigt hvor ihærdigt jeg forsøger at definere mig selv - gennem det, jeg siger og gør (gennem min selvhævdelse) - så vil mine samtalepartnere forsøge at reducere mine påstande til mit køn. Min stræben efter eksistens vil blive mødt med deres insisteren på min essens. Jeg opfatter det således, at Beauvoir er bestyrtet over sin opdagelse, og at hun derfor nærer et stærkt ønske om, at det måtte forholde sig anderledes.

Der er en yderligere komplikation i sætningen. På fransk er verbet i simpelt futurum ( enlèvera). Parshleys engelske oversættelse anvender ordet must: "on this truth must be based all further discussion". Det kunne give det indtryk, at Beauvoir mener, det er en ønskværdig situation; måske endog at hun mener, at det faktum, at man er kvinde, altid bor tages i betragtning. Men Parshley overser her nogle gængse nuancer i fransk futurum tempus. "Tu ne sortiras pas" bærer sædvanligvis nogle konnotationer som "du får ikke lov til at gå ud" eller "Jeg forudsiger, at du ikke vil kunne klare at komme ud af huset". Der er ofte en bibetydning af tvang, dvs. af at være underlagt en andens vilje eller af en uafvendelig skæbne ( du vil under ingen omstændigheder kunne undslippe denne skxbne ). Beauvoir siger rent faktisk ikke, at kønnet som baggrund skal tages i betragtning, hver gang en kvinde taler, ej heller siger hun, at det $b ø r$ tages i betragtning. Hun siger, at det vil blive taget i betragtning, hvadenten kvinden ønsker det eller ej, og hvadenten det er relevant eller ej for det, som hun hævder. Med andre ord: Betydningen af sætningen er, at hver gang en kvinde udtaler sig, vil hendes køn altid blive taget $\mathrm{i}$ betragtning.

Det er en modsætning til mænds situation, idet mænds udtalelser ikke automatisk opfattes på baggrund af en kønnet - mandlig - krop, hver gang de åbner munden. Som Nancy Bauer har vist: Bare ved at sige, at hun er en kvinde, angiver Beauvoir, at hun forkaster den kartesianske opsplitning mllem krop og sjæl:

"Det viser sig (...) at det første, Beauvoir har at sige om sig selv, er, at hun er en kvinde. Det indebærer, at i modsætning til Descartes begynder Beauvoir med en grundsætning om sin krops betydning, og hendes tænkning kan følgelig ikke rumme en kartesiansk splittelse mellem ånd og krop. Eftersom hendes undersøgelse er rodfæxstet i hendes opfattelse af sig selv som et eksempel på det generiske begreb kvinde, undgår hun desuden fra starten en vis kartesiansk solipsistisk trussel: Idet hun kalder sig en kvinde, begynder hun med den opfattelse, at der eksisterer andre mennesker som hende - det vil sige, andre mennesker som kaldes, ellers som kalder sig selv, kvinder" (Bauer 1992, 60).

Beauvoir skriver: "En mand begynder aldrig med at erklære, at han er et individ af et bestemt køn; at han er en mand, siger sig selv". Det, som indledes her, er et skrift, sandsynligvis et filosofisk essay. Beauvoir hævder, at fordi hun er en kvinde og ikke en mand, vil alt, hvad hun siger ( hævder eller postulerer ) i "Det andet køn" blive relateret til det faktum, at hun har en kvindekrop. Den måde, hendes bog blev modtaget på i Frankrig, var et tydeligt bevis på, at hun havde ret. ${ }^{6}$

Men der er mere i det end som så. For Beauvoirs sætning: "Men hvis jeg vil definere mig selv, må jeg allerførst sige: Jeg er en kvinde; denne sandhed er den baggrund som alle yderligere påstande vil blive set i relation til" skaber en stærk intertekstuel anknytning til en passage i forordet til Maurice Merleau-Pontys "Phenomenology of Perception":

Perception er ikke viden om verden, den er ikke engang en handling; en bevidst indtagelse af en position; den er baggrunden [fond] mod hvilken alle handlinger fremstår [se détachent] og forudsættes af dem. Ver- 
den er ikke et objekt i den forstand, at jeg er i besiddelse af nøglen til dens skabelse, den er den naturlige baggrund for, og et felt for, alle mine tanker og hele min eksplicitte perception (Merleau-Ponty 1945, X$\mathrm{XI})$.

Merleau-Ponty skriver dette i en kontekst, hvori han vil forklare, at kroppen giver os vores perceptioner, og at uden perceptioner eksisterer verden ikke. Kroppen er på én gang vores eksistens og det medium, gennem hvilket vi kan opleve verden. Når han taler om kropslig perception,bruger Merleau-Ponty det samme billedsprog med forgrund og baggrund som Beauvoir, når hun taler om det faktum, at hun har en kvindekrop. For Merleau-Ponty er kroppen den nødvendige baggrund for alt, hvad jeg gør, og alt, hvad jeg gør, har den opfattende krop som sin åbenbare forudsætning. Denne baggrund er noget i retning af en almen (ikke specifik eller individuel) betingelse for menneskelig handling og subjektivitet. Ved at tale om baggrund og forgrund har Merleau-Ponty til hensigt at advare mod en scientistisk eller positivistisk reduktionisme. En baggrund er ikke det samme som betydningen eller essensen af det, der foregår i forgrunden: De naturlige kropsfunktioner kan ikke i sig selv forklare menneskers handlinger og tanker. På den anden side kan den specifikke baggrund, som kroppen udgør, ikke borttænkes eller fornægtes eller antages at være uden indvirkning på forgrunden. Man kan sige, at Merleau-Ponty sætter en fænomenologisk materialisme op imod Kants idealisme og scientistiske positivisme. ${ }^{7}$

At betragte kroppen som baggrund er at indrømme, at dens betydning for vores projekter og identitetsfølelse varierer. Merleau-Pontys visuelle metafor [se détacher] får mig til at tænke på teatret og på landskaber. I et skuespil er baggrunden - bagtæppet - i nogle tilfælde afgørende for forståelsen af skuespillernes ord og gestus, mens det $\mathrm{i}$ andre tilfælde ville være helt for- kert at fokusere for meget på baggrunden. Lad os forestille os en bygning placeret på baggrund af et dramatisk landskab. Hvis det er bygningen, jeg vil studere, er landskabet blot en baggrund, som jeg ikke behøver at tage hensyn til overhovedet. Hvis det derimod er landskabet, der er i fokus, kan bygningen enten betragtes som en del af det, eller der kan ses bort fra den. Baggrunden er der altid, men dens betydning er langt fra givet.

Beauvoirs taktile metafor har lidt afvigende konnotationer. Relieffet på en skulptur kan beundres for sin egen skyld. Men oftest vil det være ret vanskeligt at fokusere på relieffet uden at bemærke den skulptur, det er en del af. En skulptur frembringer en mere integreret enhed mellem forgrund og baggrund end et bagtxppe på en scene eller landskabet bag ved en italiensk kirke. Forskellen i brugen af metaforer signaliserer en forskel i eftertryk. Idet Beauvoir vælger senlever frem for se détacher, bruger hun bevidst et billede, som gør det mere vanskeligt at fokusere på forgrunden uden at tage hensyn til baggrunden end MerleauPontys se détacher. Hendes metafor tager sexisme (med) i betragtning; det gør Merleau-Pontys ikke. Ved at betragte den kønnede krop som en baggrund, som kvinden er tvunget til at sætte $\mathrm{i}$ forgrunden, hver gang hun bliver bedt om at definere sig selv, angiver Beauvoir, at for en kvinde, der lever under patriarkatet, er kroppen et meget mere ubestrideligt faktum, end det er for en mand. Hvad kvinden end siger, vil hendes krop - hendes kvindekøn - blive taget i betragtning. Vi må understrege, at det i nogle tilfælde er - og i andre tilfælde ikke er - det, kvinden ønsker. Ved at tænke i begreberne forgrund og baggrund undgår Beauvoir at implicere, at kvinders udsagn kan reduceres til deres kroppe.

I det første kapitel i min kommende bog bruger jeg en del tid på at diskutere Beauvoirs påstand om, at kroppen er en situation, en fundamental del af levet erfaring. Hvilken forskel er der på at forstå kroppen 
som en situation og som en baggrund? I Beauvoirs udsagn er kroppen betragtet som baggrund fremstillet som en krop, der opfattes af den Anden. Den Andens nærværelse ligger implicit i forsøget på at definere én selv (man opfatter det sjældent som nødvendigt at erklære "Jeg er en kvinde" over for sig selv), og det er eksplicit til stede i påstanden om, at denne definition er et resultat af en underkastelse under en ydre forpligtelse. Begrebet situation forudsætter også, at der er andre mennesker i verden, $o g$ at vi indgår i relationer med dem. Men det er ikke et begreb, som udelukkende angår kroppen. Kroppen er en situation, men det er det også at gå i gymnasiet eller at være gift. Disse situationer kan imidlertid ikke opfattes som baggrund [fond] med den betydning, som Beauvoir tillægger begrebet. Kroppen som situation er kroppen, som den opleves af subjektet, kroppen som sammenvævet med subjektets projekter. Opfatter man derimod kroppen som en generel baggrund for min eksistens, går kroppen forud for og muliggør perception og erfaring. Mens kroppen som situation forudsætter handling hos subjektet, så muliggør kroppen som baggrund handling. Det er i hvert fald det indtryk, jeg får ved at læse Merleau-Ponty. I det udsagn, som analyseres, synes Beauvoir imidlertid at bruge ideen om kroppen som baggrund lidt anderledes, idet hun helt bevidst vælger at betragte den handlende og situerede krop som baggrund. Dette bliver klart, når hun går over til at diskutere en kvindes assertioner $i$ en abstrakt diskussion med en mand. Den faktiske, fysiske kvindekrop, som sidder dér ved cafébordet og diskuterer filosofi, er både en situation for kvinden som taler og en baggrund for hendes udsagn for den mand, der taler med hende.

Det samme udtryk - at stå frem i relief mod en baggrund - dukker også op i indledningen til bind 2 af "Det andet køn" med titlen "Lexpérience vacuum", eller som på engelsk "Lived Experience". I denne korte tekst skriver Beauvoir, at kvinder er begyndt at hævde deres selvstændighed. Det sker imidlertid ikke uden vanskeligheder, for mandlig prestige er langt fra udryddet. For at forstå, hvad det betyder for moderne kvinder at hævde deres selvstændighed, er det vigtigt at studere kvinders traditionelle skxbne, og Beauvoir afslutter indledningen som følger:

Jeg skal forsøge at beskrive, hvordan kvinden erfarer sin situation, hvordan hun oplever den, i hvilken type univers hun bliver indespærret, hvilke former for flugt der tillades hende. Kun på denne måde kan vi forstå, hvilke problemer der opstår for kvinder, som, med en tung fortid som arv, stræber efter at forme en ny fremtid. Når jeg bruger ordene kvinde, feminin eller kvindelig , ${ }^{8}$ refererer jeg helt klart ikke til noget arketypisk, til nogen uforanderlig essens; efter de fleste af mine udsagn [ mes affirmations] bør læseren underforstå med det nuværende uddannelsessystem og traditioner. Pointen her er ikke at proklamere evige sandheder, men snarere at beskrive den almene baggrund [fond], hvorfra enhver specifik kvindelig eksistens står frem [ sur lequel senlève toute existence féminine singulière] (SSxxxvi; DSb9; TA $)^{9}$

Bind 2 af "Det andet køn" er inddelt i fire hovedafsnit med overskrifterne "Education" [Formation]. "Situation", "Justifications" og "Towards Liberation". Dette bind er blevet meget kritiseret, som oftest med den begrundelse at Beauvoir generaliserer ud fra et ikke repræsentativt eksempel, idet hun tager sin mors generation og sine egne franske erfaringer som repræsentative for kvinder overalt. Det antages også ofte, at hun mener, at de situationer, hun beskriver, er af en sådan beskaffenhed, at ingen kvinde kan transcendere dem. Således opfattes hendes kritik af moderskabet eller det borgerlige xgteskab ofte som ensbetydende med, at ingen individuel kvinde nogen sinde vil kunne realisere sig selv som en autentisk fri person inden for disse institutioner. 
Hvis det var tilfældet, ville Beauvoir være en ekstrem determinist. Omvendt er det også blevet antaget, at Beauvoir er en radikal voluntarist, en idealist der mener, at kvinder - blot ved en viljesakt - kan kaste det sexistiske åg af sig og realisere sig selv, og at de ikke har andre end sig selv at bebrejde, hvis det mislykkes for dem at skaffe sig af med deres mistro. Hvis det var tilfældet, ville Beauvoir ikke have nogen grund til at hævde, at institutioner og ideologier ( myter ) undertrykker kvinder.

Når Beauvoir fremhæver samspillet mellem forgrund og baggrund, er det for at undgå reduktionisme og essentialisme (den individuelle kvinde $\mathrm{i}$ forgrunden kan ikke reduceres til den generelle historiske situation, der er hendes baggrund). Samtidig gør hun det muligt for os at forstå de historiske faktorer, der har indflydelse på og former individuelle kvinders valg. I "Det andet køn" forsøger Beauvoir at fremsætte en historisk analyse af kvinders situation. En historisk analyse kan ikke være altomfattende eller universel i den forstand, at den kan nå et sådant abstraktionsniveau, at den kommer til at gælde for alle kvinder $\mathrm{i}$ alle lande til alle tider. Hvis den overhovedet skal have nogen analytisk og historisk gyldighed, må den være specifik og partikulær. Selv om vi kan mene, at det ikke er rimeligt, når Beauvoir tager udgangspunkt i kvinder med det nuværende uddannelsessystem og traditioner [i Frankrig] ville vi, hvis vi ønskede at korrigere hende, blot kunne foreslå, at hun i stedet skulle se på en anden gruppe. Eftersom ingen bestemt gruppe er mere universel end nogen anden gruppe, ville det ikke gøre analysen mere repræsentativ for kvinders situation end den, Beauvoir fremsætter. ${ }^{10}$

Beauvoir forsøger ikke at beskrive eller forudsige, hvad den enkelte kvinde vil få ud af de livsbetingelser, hun er opvokset under. Hendes eget liv var yderst usædvanligt for en kvinde i Frankrig i midten af det 20. århundrede. Alligevel mener hun fuldt og fast, at det var præget og formet af den tra- ditionelle baggrund, hun beskriver i "Det andet køn". Idet hun beskriver, hvordan hun fik øjnene op for den patriarkalske mytologi, skriver hun: 'Det var en åbenbaring for mig: Verden var mandlig, min barndom var blevet næret af myter skabt af mænd, og jeg havde ikke reageret på dem på samme måde som jeg ville have gjort, hvis jeg havde været en dreng.'ll Beauvoirs fundamentale forståelse af subjektivitet baseres på den antagelse, at vi bestandig gør noget ud af det, som verden gør ved os. Den baggrund, hun beskriver og analyserer $\mathrm{i}$ bind 2 af "Det andet køn", fortæller os, hvad omverdenen ønsker at gøre kvinder til. Hun inkluderer også mange enkelttilfælde og utallige eksempler, hvori hun viser, hvad kvinder, når de reagerer på deres situation, får ud af det, omverdenen gør dem til. Alene det faktum, at Beauvoir ret ofte dvæler ved exceptionelle kvinder, demonstrerer, at hun ikke opfatter sin beskrivelse af den generelle historiske og sociale baggrund som ugyldig, selvom hun flytter sit fokus til et specifikt enkelttilfælde og trækker det frem i forgrunden, hvor exceptionelt det end måtte være.

Endelig giver Beauvoirs udsagn denne sandhed er den baggrund... mulighed for to vidt forskellige politiske tolkninger. På den ene side kan det opfattes, som om hun mener, at i et sexistisk samfund (som i Paris 1949) vil en kvindes udsagn altid blive opfattet med henvisning til hendes krop, mens det i et ikke-sexistisk samfund ikke længere vil være tilfældet. På den anden side kan det, hun siger, også opfattes således, at selv om det er sexistisk at insistere på at læse en kvindes bøger på baggrund af hendes køn, så vil det samme ske for mænd i et ikke-sexistisk samfund. Dette er den feministiske konflikt indkapslet i en nøddeskal, nemlig konflikten mellem en vis forståelse af lighed og en vis forståelse af forskel. ${ }^{12}$ Siger Beauvoir så, at det er feminismens mål at gøre kønsforskellen irrelevant, og at vi alle bør behandles som de mennesker, vi er? Eller siger hun, at det er feminismens mål at vise, 
at kønsforskellen er relevant til alle tider og i enhver social og individuel kontekst? 13

For det første er det vigtigt at bemærke, at Beauvoirs udsagn ikke kun kan tolkes på én af de to måder. Der er intet, der angiver, at det, hun egentlig mener, er det ene eller det andet. For det andet ser det ud til, at ingen af de to fortolkninger svarer til logikken i Beauvoirs tekst. Den første tolkning (at kønsforskellen er irrelevant) lyder blot som et ekko af den humanistiske nominalisme, hun eksplicit forkastede en side forinden: Det er klart, at ingen kvinde uden ond tro kan pretendere at overskride sit køn. Den anden tolkning (at kønsforskellen altid er af fundamental betydning) er heller ikke overbevisende, i og med at den făr kønsforskellen til at synes absolut (eller essentiel) ved at antage, at der ikke kan være nogen situation, hvor den ikke er en signifikant faktor. Det er et synspunkt, der ikke harmonerer med Beauvoirs fundamentale eksistentialistiske overbevisning om, at eksistens går forud for essens.

Ved at tænke på kroppen som baggrund undgår Beauvoir begge de to tolkninger. At sige, at den kønnede krop er den uundgåelige baggrund for alle vores handlinger, er på én gang at udsige, at den altid er en potentiel kilde til betydning, og samtidig at benagte, at den altid er nøglen til betydningen af en kvindes handlinger. Et skulpturelt relief kan ikke altid forstås ved at referere tilbage til den overflade, det fremstår ud fra. I nogle tilfælde må vi nødvendigvis forstå relieffet i sig selv. I andre tilfælde må vi overveje, hvordan relieffet indvirker på skulpturen som helhed og vice versa. I atter andre tilfælde vil vi se hele skulpturen som en del af en større kontekst. Kort sagt er den kønnede krop altid til stede, men det er ikke altid, at dette er det mest betydningsfulde faktum ved kroppen. En døende krop, eller en krop der føler smerte, bliver ikke nødvendigvis opfattet primært som kønnet. Hvis jeg forsøger at lære kinesisk, er det klart en indsats, jeg gør på baggrund af min kønnede krop, men relevansen af at sige det er ikke altid indlysende. Men hvis jeg forsøger at blive gravid, så er det et projekt, som helt givet vil sætte min kønnede krop i forgrunden. Mere komplekse tilfælde vil opstå ved kvinders deltagelse i forskellige former for sport eller andre fysiske aktiviteter.

Det er en følge af Beauvoirs analyse, at mens kønnet i nogle situationer er mindre betydningsfuldt end klasse- eller racetilhørsforhold, så forholder det sig omvendt i andre tilfælde. Der kan ikke være tale om at give $e n$ af disse faktorer en generel, altoverskyggende prioritet. De traditionelle diskussioner om, hvorvidt klassebaseret udnyttelse eller kønsbaseret undertrykkelse er primære, er aldrig blevet overbevisende besvaret. Dette projekt vil altid vare dømt til at mislykkes, netop fordi det søger et generelt svar, et svar som kunne fastslå det "rigtige" undertrykkelseshierarki én gang for alle. Man slipper i øvrigt ikke uden om dette problem ved at benægte, at der findes undertrykkelseshierarkier. I Spanien i 1936 var det for eksempel mere vigtigt for republikanere af begge køn at kæmpe mod fascismen end mod sexisme (men det betyder ikke, at de spanske republikanere ikke var sexistiske). I andre tilfælde er der måske ikke tale om noget hierarki; kampen for kvinders ret til uddannelse kan være lige så nyttig for socialismen som for feminismen. I andre tilfælde vil kønnet være den dominerende form for undertrykkelse, hierarkisk vigtigere end den klassebaserede undertrykkelse. Det er f.eks. helt tydeligt tilfældet i Afghanistan, hvor kvinder uden mandlige familiemedlemmer dør, fordi Talibanerne ikke vil tillade dem at konsultere en læge, uden at der er en bror eller en ægtemand til stede.

Jeg opfatter Beauvoirs udsagn sådan, at kvindens undertrykkelse består $\mathrm{i}$, at kvindekroppen i alle tilfælde placeres i forgrunden, hvad enten det er relevant eller irrelevant i situationen. Men sexisme indebærer også, at kvinder forhindres $i$ at sætte kvindekroppen i forgrunden, når de ønsker, at 
den skal være betydningsfuld. (En Beauvoirsk feminist ville være kritisk over for antisex og anti-pornografisk feminisme). I en flirt- eller forførelsessituation kan en kvinde for eksempel ønske at sætte sin krop i forgrunden. Således ønsker Francoise i L invitée (Gæsten) intenst, at Gerbert skal lægge mærke til hendes kønnede krop, skal lægge mærke til hende som kvinde. Omvendt kan det dog også være generende eller pinefuldt at blive tiltalt som en kønnet krop, når man er optaget af et projekt, som ikke har noget at gøre med ens køn. Den samme logik gælder den racebestemte krop. At blive opfattet som en representant for sin race, når man er optaget af et projekt, hvori dette er helt irrelevant, kan være meget pinefuldt og ydmygende.

Frantz Fanon fanger fint den oplevelse af fragmentering og udelukkelse, der opstår, når man bliver reduceret til sin racebestemte krop imod sin vilje. I en passage i bogen "Black Skin, White Masks" (Fanon 1967) beskriver han, hvordan han går ned ad en gade $\mathrm{i}$ en fransk by og passerer en hvid kvinde og hendes lille datter på vejen. Jeg citerer episoden detaljeret, fordi den meget præcist gengiver Fanons pine og fremmedgørelse, hans følelse af at den hvide mands blik holder ham fanget i sin subjektivitet en subjektivitet, der er reduceret til det faktum, at hans hudfarve er sort:

Se, en neger! Det var en ydre stimulus, som svirpede hen over mig, idet jeg gik forbi: Jeg smilede anstrengt.

Se, en neger . Det var sandt. Det morede mig.

Se, en neger! Cirklen strammede noget til. Jeg lagde ikke skjul på min morskab.

Mor, se den neger! Jeg er bange . Bange! Bange! Nu var de ved at blive bange for mig. Jeg besluttede mig til at le til tårerne trillede, men det var blevet umuligt at le.

Jeg var ansvarlig på én gang for min krop, for min race, for mine forfædre. Jeg underkastede mig en objektiv undersøgelse, jeg oplevede min sorte hudfarve, mine etni- ske karakteristika; og jeg blev hamret ned af tamtamer, kannibalisme, intellektuel underlegenhed, fetichisme, racemæssige defekter, slaveskibe og fremfor alt, fremfor alt: Godt kød .

Den dag, fuldstændig udelukket, ude af stand til at færdes ved siden af den anden, den hvide mand, som ubarmhjertigt holdt mig fangen, fjernede jeg mig langt fra mig selv, meget langt, og gjorde mig selv til objekt. Hvordan kunne det blive andet end en amputation, en bortskæring, en blødning som oversprøjtede hele min krop med sort blod? Men jeg ønskede ikke denne revision, denne tematisering. Alt hvad jeg ønskede var at være en mand blandt mænd. Jeg ønskede at komme smidig og ung ind $\mathrm{i}$ en verden, som var vores, og hjælpe til med at bygge den sammen med andre.(Fanon 1967, 112-13).

Der er situationer, hvori vi frit vælger at blive opfattet som kønnede eller racemæssige kroppe, hvor den opfattelse er præcis det, vi har brug for og ønsker. Identitetspolitik begynder med den slags identitetsbekræftende situationer, men den går uheldigvis videre til at basere en generel politik på disse situationer og overser dermed, at der er andre situationer, hvor vi ikke ønsker at blive defineret af vores kønnede og racemæssige kroppe, situationer hvor vi ønsker, at vores krop kun skal være den underordnede baggrund for vores hovedaktivitet. Som vi skal se, giver Beauvoir selv et udmærket eksempel på netop sådan en situation, idet hun nævner et konkret tilfælde, hvor en mand i en abstrakt samtale siger til hende: Det siger De, fordi De er en kvinde. Selv om denne oplevelse måske er meget mindre pinefuld for den intellektuelle kvinde, end oplevelsen af racisme var for Fanon, så afslører sidestillingen af de to situationer, at parallelle undertrykkelsesmekanismer udspiller sig i mødet mellem den racemæssige og kønnede krop og den Anden. ${ }^{14}$

Det er fristende at sige: I visse situationer ønsker jeg at blive opfattet som intellektuel 
og ikke primært som kvinde. Men problemet med det udsagn er, at det ikke udtrykker præcis det, jeg vil sige. Det kan alt for let opfattes som, at jeg i nogle situationer ønsker at fornagte, at jeg er en kvinde - og således vil anklage mig selv for at være en af de humanistiske nominalister, der foregiver at overskride mit køn. ${ }^{15}$ Men jeg ønsker ikke at påstå, at min krop ikke eksisterer, eller at jeg ikke er en kvinde. Beauvoir hjælper mig til at formulere det klarere: I visse tilfælde ønsker jeg, at min kvindekrop bliver opfattet som en temmelig betydningsløs baggrund for mine udsagn eller handlinger. Jeg ønsker ikke, at min krop skal forsvinde eller omformes til en mandekrop. Mit ønske er ikke et forsøg på at flygte fra min særegenhed, på at blive opfattet som intetkøn eller som en form for universelt menneskeligt væsen. Det er snarere et ønske om at kunne benægte, at det faktum, at jeg er kvinde, har nogen som helst relevans for min forståelse af trigonometri eller min evne til at komponere symfonier eller tænke etisk.

Jeg vil gerne indrømme, at jeg sandsynligvis læser Kant eller Kierkegaard anderledes, end jeg ville have gjort, hvis jeg havde været en mand. Men selv om jeg ofte læser som en kvinde, vil jeg ikke derved have berøvet mig retten til at være intellektuel. Er det nødvendigt, at jeg altid refererer til mig selv som en intellektuel kvinde? Mænd, der læser Kant og Kierkegaard på måder, som de ikke ville have gjort, hvis de var kvinder, refererer sædvanligvis til sig selv som intellektuelle eller filosoffer og ikke som intellektuelle mænd eller mandlige filosoffer . Dette faktum fører ikke til, at de bliver anklaget for at fornægte eller undertrykke deres maskulinitet, eller at de bliver betragtet som mænd med kvindelig identifikation. Ifølge sexistisk ideologi kan mænd være indlysende mandlige og indlysende intellektuelle på samme tid. Derfor lyder vendingen en intellektuel mand mærkelig, mens en intellektuel kvinde lyder helt normalt. Det er Beauvoirs femini- stiske mål at frembringe et samfund, hvor kvinder vil få adgang til det universelle som kvinder og ikke som påtagede mænd eller som kønsløse væsener. ${ }^{16}$

Lige siden feminismen blev en del af det offentlige liv, har der været kvindelige forfattere, malere osv., der har følt, at feminismen er en ideologi, som låser kvinder inde $\mathrm{i}$ deres partikulære kvindelige subjektivitet. Af samme grund har de ment, at det var antifeministisk at modsætte sig at blive kaldt kvindelig forfatter og kvindelig maler osv. Mange feminister har været enige i, at der er noget antifeministisk ved at nægte at kalde sig kvinde, og de har ofte reageret ved at beskylde sådanne kvinder for at identificere sig med mænd og mangle solidaritet med deres eget køn. Det er imidlertid et faktum, at disse kvinder i mange situationer gør ret i at modsætte sig forsøg på at sætte lighedstegn mellem kvinders subjektivitet og deres feminitet. Problemet er, at ved fuldstændigt at afvise betegnelsen kvinde trækker de deres påstand om universalitet frem $\mathrm{i}$ forgrunden og ofrer dermed deres feminitet (i denne forbindelse betyder ordet simpelthen deres kvindelighed). De overser, kunne en efterfølger af Beauvoir sige, at den kønnede krop både er en baggrund og en situation og følgelig ikke et fænomen, som man simpelthen kan fornægte. En feministisk position ville afvise begge alternativer og snarere insistere på, at kvinder ikke burde behøve at vælge imellem at kalde sig kvinder eller at kalde sig forfattere (eller intellektuelle, eller malere, eller komponister). Det er netop Beauvoirs position i "Det andet køn", idet hun betragter denne fremmedgørende splittelse i kvinders subjektivitet som et resultat af sexistiske ideologier og praksis.

Sagt på en anden måde: Det er ikke indlysende, at det, en kvinde gør eller siger, altid er et udtryk for kvinden i hende. Men samtidig er det ubestrideligt sandt, at alt, hvad en kvinde gør eller siger, gøres eller siges af en kvinde. Det er fordi begge udsagn er sande, at vi bliver så forvirrede over, 
hvad feminitet egentlig betyder. Det mest beundringsværdige ved Beauvoirs forståelse af, hvad en kvinde er, er præcis hendes evne til at gengive denne dobbelthed uden at reducere den til den ene eller anden komponent, uden at affinde sig med den, uden at vælge den ene af to lige utilfredsstillende teorier om, hvad en kvinde er ( en kvinde er blot et menneske versus en kvinde er altid blot en kvinde ).

Ved at betragte kroppen som en baggrund erklærer Beauvoir på én gang, at kønsforskellen er et faktum af fundamental filosofisk og social betydning, og at den ikke nødvendigvis altid er det vigtigste faktum ved et menneske. Fordi hun fremstiller den kønnede krop som den fænomenologiske baggrund (ikke som indholdet, essensen eller betydningen), imod hvilken en kvindes valg og handlinger vil fremstå som forgrund, er disse ikke modstående udsagn. Sagt på en anden måde, så afslører Beauvoirs formulering ( Jeg er en kvinde: denne sandhed er baggrunden...) at hendes grundlliggende feministiske projekt er at finde en måde at tænke kønsforskellen på, som styrer uden om det Skylla, som det er at eliminere sin kønnede subjektivitet, og det Karybdis, som det vil være at forblive indespærret $\mathrm{i}$ den. ${ }^{17}$

\section{Oversat af Dorrit Einersen Lektor ved Engelsk Institut Københavns Universitet}

\section{Noter}

1. (Essayet er skrevet på engelsk, og nærværende artikel handler primært om den engelske oversættelse af Simone de Beauvoirs værk "Le deuxième sexe", på engelsk"The Second Sex", på dansk "Det andet køn". Derfor er henvisninger til bogtitler, kapiteloverskrifter i essayet og centrale ord i den engelske oversættelse anført i gåseøjne på engelsk. OA.

2. Se kapitel 2 i min bog "Simone de Beauvoir: The Making of an Intellectual Woman" for en række forskellige eksempler.
3. Lénoncé même du problème me suggère aussitôt une première réponse. Der er adskillige oversættelsesmæssige problemer her. Den primære og mest gængse betydning af énoncé er sammenfaldende med énonciation eller déclaration. Men vendingen énoncé du problème betyder almindeligvis den nøjagtige formulering af et problem. Sprogligt set er lénoncé, efter Benveniste, kommet til at betyde udsagnet over for lénonciation, ytringen, talehandlingen. I betragtning af at Benveniste først offentliggjorde denne distinktion efter 1949, er den sandsynligvis ikke relevant i denne forbindelse. For en gangs skyld er jeg enig med Parshley og vælger den mest gængse betydning, nemlig det at ytre eller erklære noget .

Parshley oversætter une première réponse som a preliminary answer (et foreløbigt svar). Jeg mener ikke, at det svar, der gives her, er foreløbigt i den forstand, at det er et forord eller en preambel til et efterfølgende mere substantielt svar. Jeg mener snarere, at det er det første af to svar, der har lige megen vægt. (Det andet svar, der gives i denne paragraf på spørgsmålet Hvad er en kvinde? , er Kvinden er den Anden ).

4. Beauvoir skriver: la situation singulière qu occupent dans l humanité les màles. I denne forbindelse indføjer hun en fodnote, som fastslår, at Kinseyrapporten kun omtaler mandlig seksualitet, hvilket er noget helt andet.

5. Jeg vender tilbage til oversættelsen af denne betydningsfulde sætning.

6. Som en opsummering af modtagelsen af "Det andet køn" i "Force of Circumstance" skriver Beauvoir: Utilfredsstillet, frigid, priapisk, nymfoman, lesbisk, med hundrede aborter, jeg var det hele, endog moder i al hemmelighed (...) Men at selv [Francois] Mauriac stemte i! Han skrev til en af bidragyderne til "Les Temps Modernes": Deres overordnedes vagina har ikke mere nogen hemmeligheder for mig (197; "La force des choses", bind 1, 260-1; TA).

7. For en yderligere diskussion af Merleau-Pontys og Beauvoirs kritik af scientisme og positivisme se kapitel 1 i min kommende bog.

8. Beauvoir skriver: les mots femme ou féminin . For at understrege, at det franske ord féminin kan referere til såvel biologisk som kulturelt betinget køn, har jeg valgt at oversætte det som feminin eller kvindelig . Se kapitel 1 af "What is a Woman?" for en grundig diskussion af biologisk og kulturelt betinget køn og "Det andet køn".

9. Jævnfør H.M. Parshleys oversættelse: It is not our concern here to proclaim eternal verities, but rather to describe the common basis that underlies every individual feminine existence. (Det er ikke 
vores anliggende her at udsige evige sandheder, men snarere at beskrive den fælles basis, der underligger enhver individuel kvindelig eksistens).

10. Jeg vender tilbage til spørgsmålet om eksemplaritet og repræsentativitet i sidste afsnit af mit essay (se "What is a Woman?") i kapitel 2.

11. "Force of Circumstance" 103; La force des choses, bind 1, 136; TA.

12. Jævnfør min diskussion af den utilfredsstillende modsætning mellem en ligheds- og en forskelsfeminisme i "Is Anatomy Destiny?" (kapitel 9 i "What is a Woman?").

13. Der er tydelige paralleller mellem dette udsagn og den idé, som diskuteres i første del af det længere essay, som denne artikel er et uddrag af, at location [position] altid har betydning for enhver talehandling. Jeg vil understrege, at jeg ikke forsøger at benagte, at køn eller position altid er relevante. Jeg forsøger snarere at forskyde argumentationen hen imod et andet spørgsmål, nemlig spørgsmålet om, hvornår (under hvilke omstændigheder) det er væsentligt at sige noget om køn eller position.

14. Jeg hævder ikke, at Fanon og Beauvoir forstår racisme og sexisme på nøjagtig samme måde. For en kortfattet sammenligning mellem de to forfattere jævnfør kapitel $8 \mathrm{i}$ "Simone de Beauvoir: The Making of an Intellectual Woman".

15. I det første afsnit af "Det andet køn" afviser Beauvoir opfattelsen af, at kvinden er blot et menneske, lige så eftertrykkeligt, som hun afviser ideen om, at der er en kvindelig essens.

16. I "What is a Woman?' And other Essays" vender jeg tilbage til mænds ideologisk priviligerede relation til det universelle og dermed til det filosofiske mere udførligt; her vil jeg blot hejse flaget for emnets betydning.

17. Det er et udsagn, jeg diskuterer udførligt i “ 'What is a Woman?' And Other Essays"

\section{LITTERATURLISTE}

- Bauer, Nancy (1997): Recounting Woman: Simone de Beauvoir and Feminist Philosophy, Harvard University, Cambridge Mass.

- Beauvoir, Simone de (1987): Force of Circumstance., Penguin, Harmondsworth

- Beauvoir, Simone de (1989): The Second Sex, Vintage Books.

- Fanon, Frantz (1952): Black Skin, White Masks, Grove Weidenfeld, New York.

- Merleau-Ponty, Maurice (1962): Phenomenology of Perception, Routledge, London.

- Moi, Toril (1994): Simone de Beauvoir: The Making of an Intellectuel, Blackwell, Oxford - Moi, Toril (1999): What Is a Woman? And Other Essays, Oxford University Press, Oxford (under udgivelse)

\section{SUMMARY}

The article discusses the possibilities of writing theory as a woman without neglecting the claims of the female body. Through a close reading of The Second Sex the author discusses the possibilities of situating the body as either background or foreground depending on the situation of enunciation. Following Beauvoiris analyses the article concludes that while in some situations the fact of sex will be less important than the fact of class or race, in other situations it will not. The oppression of women consists in the compulsory foregrounding of the female body at all times, whether it is relevant or irrelevant to the task in hand.

Toril Moi, professor, Duke University, USA. 